University of Nebraska - Lincoln

DigitalCommons@University of Nebraska - Lincoln

Faculty Publications from the Harold W. Manter Laboratory of Parasitology

6-1996

\title{
A Survey of the Coccidian Parasites of Reptiles from Islands of the Galápagos Archipelago: 1990-1994
}

Lee Couch

University of New Mexico, Icouch@unm.edu

Paul A. Stone

Donald W. Duszynski

University of New Mexico, eimeria@unm.edu

Howard L. Snell

Heidi M. Snell

Follow this and additional works at: https://digitalcommons.unl.edu/parasitologyfacpubs

Part of the Parasitology Commons

Couch, Lee; Stone, Paul A.; Duszynski, Donald W.; Snell, Howard L.; and Snell, Heidi M., "A Survey of the Coccidian Parasites of Reptiles from Islands of the Galápagos Archipelago: 1990-1994" (1996). Faculty Publications from the Harold W. Manter Laboratory of Parasitology. 183.

https://digitalcommons.unl.edu/parasitologyfacpubs/183

This Article is brought to you for free and open access by the Parasitology, Harold W. Manter Laboratory of at DigitalCommons@University of Nebraska - Lincoln. It has been accepted for inclusion in Faculty Publications from the Harold W. Manter Laboratory of Parasitology by an authorized administrator of DigitalCommons@University of Nebraska - Lincoln. 


\title{
A SURVEY OF THE COCCIDIAN PARASITES OF REPTILES FROM ISLANDS OF THE GALÁPAGOS ARCHIPELAGO: 1990-1994
}

\author{
Lee Couch, Paul A. Stone, Donald W. Duszynski, Howard L. Snell, and Heidi M. Snell \\ Department of Biology, The University of New Mexico, Albuquerque, New Mexico 87131
}

\begin{abstract}
From 1990 through 1994, fecal samples were collected and examined for coccidian parasites from 26 giant land tortoises Geochelone nigra, from 715 lava lizards Tropidurus spp., from 139 land iguanas Conolophus subcristatus, and from 128 marine iguanas Amblyrhynchus cristatus, all of which inhabit various islands in the Galápagos Archipelago. None of the samples from $A$. cristatus or from $C$. subcristatus was infected with coccidia. Only 1 of $26(4 \%) G$. nigra was infected with a single Eimeria species that we describe here as new. A total of 262 of $715(37 \%)$ individuals representing 3 species of Tropidurus discharged oocysts of 1-3 different coccidian species; these included 2 previously described species Eimeria tropidura and Isospora insularius, and an eimerian that we describe here as new. Additionally, 104 fecal samples from Tropidurus spp. were from 51 animals recaptured in either 2 or $3 \mathrm{yr} ; 21$ had no infections in any year, 15 were infected at least once, 14 were infected in $2 \mathrm{yr}$, and only 1 was infected during 3 yr. No animal was recaptured and sampled during each of the 4 yr of this study. Of the 262 infected individuals, $30(12 \%)$ had multiple coccidial infections at the time of collection (eimerian and isosporan, or 2 eimerians). Where determination of the sexes was possible in the lava lizards, there was no difference in prevalence rates between males (39\%) and females (41\%). Sporulated oocysts of the new eimerian from Tropidurus are ellipsoidal, $27.1 \times 15.6(25-31 \times 14-18) \mu \mathrm{m}$, with a polar body, but without a micropyle or oocyst residuum; they contain ellipsoidal sporocysts, $11.8 \times 6.7(10-14 \times 6-8) \mu \mathrm{m}$, without Stieda, sub-, or parastieda bodies, but with a sporocyst residuum. Sporulated oocysts of the new eimerian from $G$. nigra are ellipsoidal to ovoidal, $21.6 \times 18.1(18-25 \times 16-20) \mu \mathrm{m}$, with a large polar body, but without a micropyle or oocyst residuum; they contain ellipsoidal sporocysts $10.7 \times 7.0(8-12 \times 5-8) \mu \mathrm{m}$, with Stieda body but no sub- or parastieda bodies. Also present is a sporocyst residuum of medium to large granules randomly distributed among the sporocysts.
\end{abstract}

Long-term research and management programs of all Galápagos reptiles, but especially of the Galápagos tortoises (Geochelone nigra, see Iverson [1992] for discussion of tortoise taxonomy) and land iguanas (Conolophus subcristatus), have been in place since 1965 (for review, see Cayot et al. [1994]). Since 1987, we have been conducting an ongoing study of the coccidia, hemoparasites, and ectoparasites that infect lizards from various islands of the Galápagos Archipelago, off the coast of Ecuador (Fig. 1). Three genera of endemic lizards dominate the islands in the Galápagos Archipelago: land iguanas (C. subcristatus), which have become locally extinct on several islands (Snell et al., 1984; Marquez et al., 1986) due to the introduction of exotic predators (cats, dogs, pigs, rats); lava lizards (Tropidurus spp.), nearly ubiquitous in the Archipelago, the populations of which are isolated from each other by island; and marine iguanas (Amblyrhynchus cristatus), primarily algal feeders that occur along the coastlines on all islands and which are capable swimmers that have the potential to move from one island to another. One of our goals is to try to determine parasite prevalences in these host populations from the different islands.

Of the 4 host genera examined in this study, only 2 (Conolophus and Tropidurus) have been examined for coccidia, and for these 2 genera, there is only a single preliminary report from our own laboratory (Aquino-Shuster et al., 1990). The work described herein is part of a larger, ongoing study of lava lizards (Snell et al. 1984, 1988; Stone, 1995), and 1 aspect of this study is to understand how parasite load is correlated with host fitness. Here we report our findings in fecal samples of Galápagos reptiles that were collected from 1990 through 1994 and examined for the presence of coccidia.

Received 25 September 1995; revised 11 January 1996; accepted 11 January 1996.

\section{MATERIALS AND METHODS}

Between 1990 and 1994, fecal samples were collected from 715 lava lizards representing 3 species of live-caught Tropidurus ( $T$. delanonis, $T$. albemarlensis, and $T$. bivittatus) from 18 islands, from 139 land iguanas (C. subcristatus) from 3 islands, from 26 giant land tortoises (G. nigra, 4 subspecies) located at the Charles Darwin Research Station on Isla Santa Cruz, and from 128 marine iguanas (A. cristatus) from 6 islands of the Galápagos Archipelago. Samples were collected opportunistically using noninvasive techniques and most samples were collected during the morning. The lava lizard samples were obtained from coastal study areas on each island; 1990-1993 samples were collected between May and August and 1994 samples were collected between January and April. Most of the marine iguanas ( 4 of 6 populations) and land iguanas ( 2 of 3 populations) were obtained by sampling from the entire population of a given island; samples from the remaining populations were obtained from coastal study areas in the mornings between May and August. The tortoise samples came from captive animals, all of which were housed in outdoor pens at the Charles Darwin Research Station on Isla Santa Cruz; these samples were collected in the mornings of August 1991. Samples were placed in separate vials containing $2 \%$ (w/v) aqueous potassium dichromate $\left(\mathrm{K}_{2} \mathrm{Cr}_{2} \mathrm{O}_{7}\right)$, mixed thoroughly, and stored at ambient temperature. Upon arrival in Albuquerque, the samples were processed using the procedure outlined by Duszynski et al. (1982), and oocysts were measured and photographed between 60 - and 800 -days-old, and stored at 4C. All measurements are given in $\mu \mathrm{m}$ with size ranges in parentheses following the means. In addition, when it was possible, the sex of each animal was determined to see if prevalence differed by gender. Finally, because all of the hosts are protected species and are part of the Galápagos National Park system, they were released once fecal samples were collected.

\section{RESULTS}

Of 715 Tropidurus samples collected, 262 (37\%) were infected; 3 different coccidians were found representing 2 species of eimerian and 1 species of isosporan (Table 1). Only 1 fecal sample from the other 3 reptile species examined was infected; of 26 samples from $G$. nigra, 1 contained a previously undescribed eimerian and no coccidian oocysts were found in 139 fecal samples from $C$. subcristatus or in 128 samples from $A$. cristatus. 

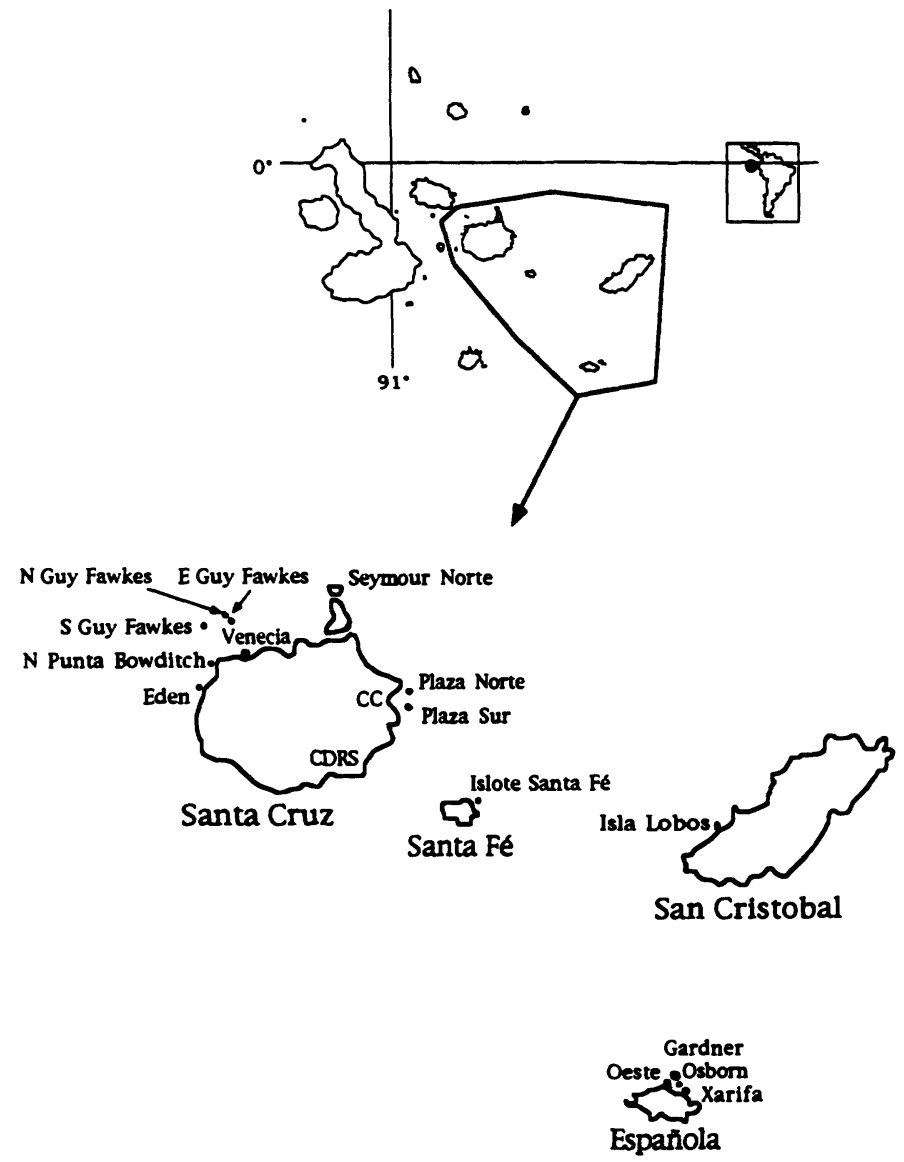

FIGURE 1. Map of the Galápagos Archipelago with inset showing the specific islands where samples were collected.

Of the 262 positive Tropidurus samples, 30 (11\%) were infected with 2 coccidian species: 17 of $184(9 \%)$ positive $T$. delanonis samples had both Eimeria tropidura and Isospora insularius and 13 of $78(17 \%)$ positive $T$. albemarlensis were infected with both $E$. tropidura and a new eimerian. The distributions of the 2 species of coccidia infecting $T$. delanonis were not independent of one another. Instead, there was a tendency for the 2 species of coccidia to be positively associated with one another (chi-square contingency table, $\chi^{2}=3.83, P=0.05$, df $=1$ ). This trend was not significant in $T$. albemarlensis (chisquare contingency table, $\chi^{2}=2.35, P>0.13$, df $=1$ ).

Prevalence of coccidians in Tropidurus varied by island, species of coccidia, and species of lizard. Between islands, prevalence varied from 0 to $75 \%$ (Table I); part of this variation is attributed to small sample size on specific islands. Across all islands, E. tropidura was the most prevalent coccidian, occurring in $28 \%$ of all hosts, whereas the other 2 species occurred only in $5-7 \%$ of all hosts sampled. Time of year appeared to have no effect on the prevalence of coccidia in lava lizards. Finally, different species of lava lizard were infected with different species of coccidia. For example, I. insularius was found only in $T$. delanonis and the new species of eimerian only in $T$. albemarlensis. Male and female lava lizards did not differ in prevalence $\left(\right.$ males $=99 / 255,39 \%$; females $=89 / 218,41 \%, \chi^{2}=$ $0.12, P=0.7, \mathrm{df}=1)$.
TABLE I. Coccidian species found in 715 samples ( 51 recaptures) from the Galápagos lava lizards, Tropidurus spp., collected from 1990 through 1994 from various islands of the Galápagos Archipelago, Ecuador.

\begin{tabular}{|c|c|c|c|}
\hline \multirow[b]{2}{*}{$\begin{array}{l}\text { Host species } \\
\text { by island (no. hosts) }\end{array}$} & \multicolumn{3}{|c|}{ Coccidian species found } \\
\hline & $\begin{array}{c}\text { Eimeria } \\
\text { tropidura } \\
\text { No. in- } \\
\text { fected (\%) }\end{array}$ & $\begin{array}{l}\text { Isospora } \\
\text { insularius } \\
\text { No. in- } \\
\text { fected (\%) }\end{array}$ & $\begin{array}{c}\text { Eimeria } \\
\text { albe- } \\
\text { marlensis } \\
\text { n. sp. } \\
\text { No. in- } \\
\text { fected (\%) }\end{array}$ \\
\hline \multicolumn{4}{|l|}{ T. delanonis } \\
\hline Española (154) & $22(14)$ & $14(9)$ & 0 \\
\hline Gardner (142) & $12(8)$ & $12(8)$ & 0 \\
\hline Oeste (10) & $3(30)$ & $1(1)$ & 0 \\
\hline Osborn (85) & $62(73)$ & $5(6)$ & 0 \\
\hline Xarifa (80) & $59(74)$ & $3(4)$ & 0 \\
\hline \multicolumn{4}{|l|}{ T. albemarlensis } \\
\hline Eden (5) & 0 & 0 & 0 \\
\hline Guy Fawkes S (2) & 0 & 0 & 0 \\
\hline Guy Fawkes N (11) & 0 & 0 & 0 \\
\hline Guy Fawkes E (5) & 0 & 0 & 0 \\
\hline Plaza Norte (13) & $2(15)$ & 0 & $3(27)$ \\
\hline Plaza Sur (132) & $33(25)$ & 0 & $45(34)$ \\
\hline Punta Bowditch Norte (5) & 0 & 0 & $1(20)$ \\
\hline \multicolumn{4}{|l|}{ Santa Cruz } \\
\hline -Ch. Darwin Sta. (4) & $3(75)$ & 0 & 0 \\
\hline -C. Colorado (13) & $4(31)$ & 0 & 0 \\
\hline Santa Fé (15) & 0 & 0 & $2(13)$ \\
\hline Santa Fé Islote (11) & 0 & 0 & 0 \\
\hline Seymour Norte (6) & 0 & 0 & 0 \\
\hline Venecia (6) & $3(50)$ & 0 & $1(17)$ \\
\hline \multicolumn{4}{|l|}{$T$. bivittatus } \\
\hline Lobos (16) & $4(25)$ & 0 & 0 \\
\hline Totals (715) & $207(28)$ & $35(5)$ & $50(7)$ \\
\hline
\end{tabular}

In addition, 104 samples came from 51 animals recaptured either 2 or 3 yr. Twenty-one had no infections in any year, 15 were infected in at least $1 \mathrm{yr}, 14$ were infected in $2 \mathrm{yr}, 1$ was infected $3 \mathrm{yr}$, and no lizard was recaptured during all $4 \mathrm{yr}$. Interestingly, of the 29 infected lizards captured in 2 or $3 \mathrm{yr}$, $15 / 29(52 \%)$ were infected with at least the same coccidian at their second or third capture as they were during their first capture (Table II).

Only 1 of $26(4 \%) G$. nigra was infected with a single eimerian species, but great numbers of oocysts were present in the 1 sample. Because of the large number and good structural condition of the oocysts observed, we suspect it is not a spurious infection or a pseudoparasite and have included a description of the new eimerian (also see Remarks section).

\section{DESCRIPTION}

Eimeria tropidura Aquino-Shuster, Duszynski, and Snell, 1990

Sporulated oocysts did not differ qualitatively or quantitatively from those found in T. delanonis samples collected prior to 1990 as described by Aquino-Shuster et al. (1990) (U.S. National Museum Parasite Collection [USNPC] no. 80919). 
TABLE II. Tropidurus spp. that were recaptured 2 or more times from 1990 to 1994 and infected with 1 or more coccidian species during at least 1 capture $(E$. trop $=E$. tropidura, I. ins. $=I$. insularius, and $E$. alb. $=$ E. albemarlensis $\mathrm{n} . \mathrm{sp})$.

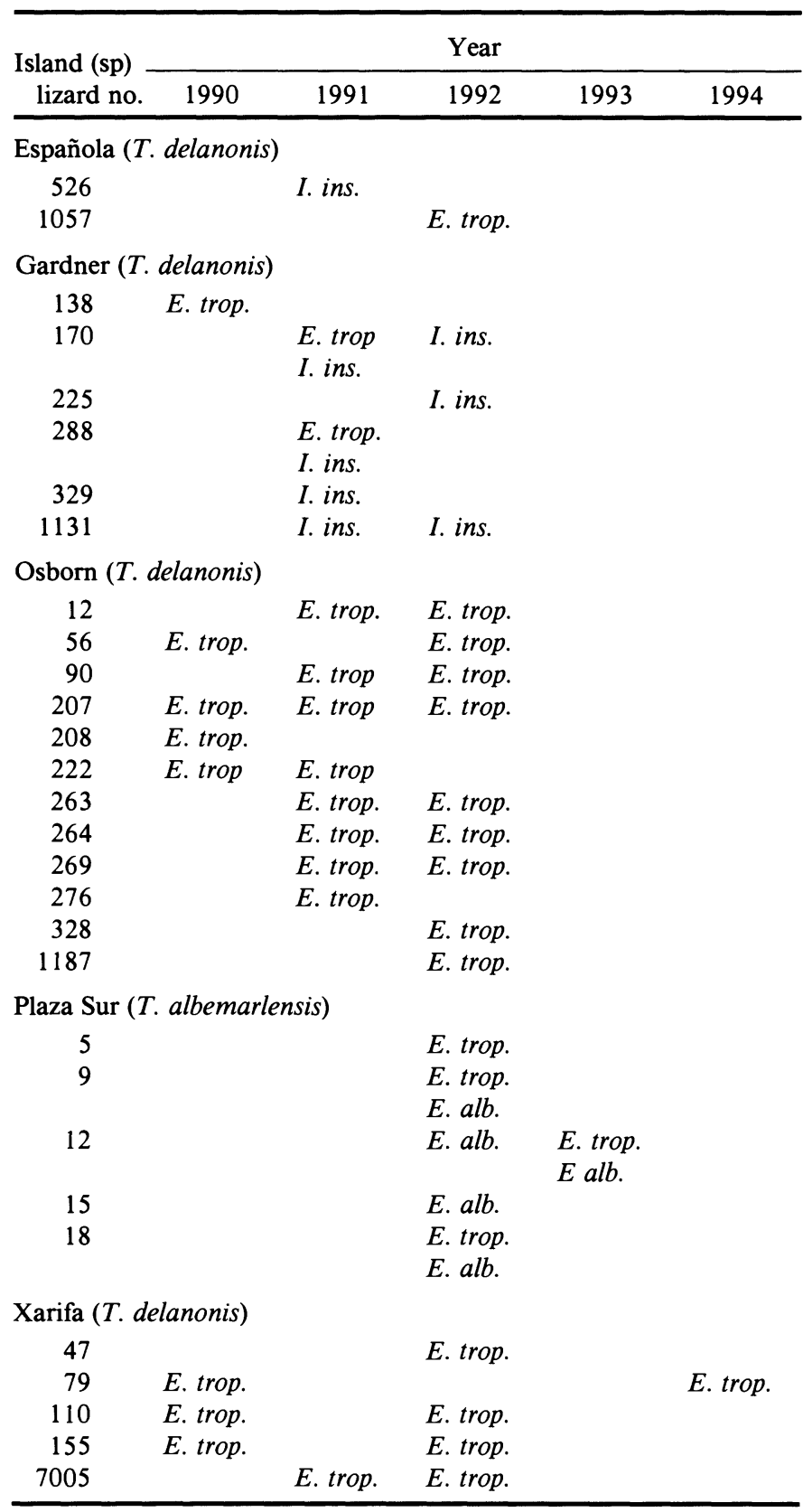

\section{Taxonomic summary}

Prevalence: Found in 158 of 471 (34\%) T. delanonis including 22 of $154(14 \%)$ from Isla Española, 12 of $142(8 \%)$ from Isla Gardner, 3 of $10(30 \%)$ from Islote Oeste, 62 of $85(73 \%)$ from Islote Osborn, and 59 of $80(74 \%)$ from Islote Xarifa; found in 45 of $228(20 \%)$ T. albemarlensis, including 4 of $13(31 \%)$ from Cerro Colorado (CC) on Isla Santa Cruz, 3 of 4 (75\%) from the Charles Darwin Research Station (CDRS) also on Isla Santa Cruz, 2 of 13 (15\%) from Isla Plaza Norte, 33 of 132 (25\%) from Isla Plaza Sur, and 3 of $6(50 \%)$ from Islote Venecia; found in 4 of $16(25 \%) T$. bivittatus from Isla Lobos (Table I).

\section{DESCRIPTION}

\section{Isospora insularius Aquino-Shuster, Duszynski,} and Snell, 1990

Sporulated oocysts did not differ qualitatively or quantitatively from those found in T. delanonis samples collected prior to 1990 as described by Aquino-Shuster et al. (1990) (USNPC no. 80921).

\section{Taxonomic summary}

Prevalence: Found in 35 of $471(7 \%) T$. delanonis including 14 of $154(9 \%)$ from Isla Española, 12 of $142(8 \%)$ from Isla Gardner, 1 of $10(1 \%)$ from Islote Oeste, 5 of $85(6 \%)$ from Islote Osborn, and 3 of $80(4 \%)$ from Islote Este.

\section{DESCRIPTION \\ Eimeria albemarlensis n. sp.}

(Figs. 2-6, 10)

Sporulated oocysts ellipsoidal, wall $\sim 0.8$, composed of 1 smooth, clear layer; micropyle and oocyst residuum absent, but distinct refractile polar body present (Figs. 2, 4); sporulated oocysts $(n=50) 27.1 \times 15.6$ $(25-31 \times 14-18)$ with length: width ratio (=shape index, SI) 1.7 (1.62.2); sporocysts $(\mathrm{n}=50)$ ellipsoidal, 11.8-6.7 $(10-14 \times 6-8)$ with SI 1.8 (1.5-2.1); Stieda, sub, and parastieda bodies absent; sporocyst residuum of medium to large granules lying in an irregular mass along center of sporocyst (Figs. 3, 4); sporozoites lie side by side along length of sporocyst.

\section{Taxonomic summary}

Type host: Tropidurus albemarlensis Baur, 1890 (Sauria: Tropiduridae).

Type locality: Ecuador, Galápagos Archipelago, Islote Venecia, $0^{\circ} 31^{\prime} 00.6^{\prime \prime} \mathrm{S}, 90^{\circ} 28^{\prime} 29.1^{\prime \prime} \mathrm{W}$.

Other localities: Isla Plaza Sur, Islote Punta Bowditch Norte, Cerro Colorado on Isla Santa Cruz, and Isla Santa Fé.

Prevalence: Found in 50 of 228 (22\%) T. albemarlensis including 3 of $13(27 \%)$ from Isla Plaza Norte, 45 of $132(34 \%)$ from Isla Plaza Sur, 1 of $5(20 \%)$ from Islote Punta Bowditch Norte, 2 of $15(13 \%)$ from Isla Santa Fé, and 1 of $6(17 \%)$ from Islote Venecia.

Site of infection: Unknown, oocysts collected from feces.

Material deposited: Phototype (see Bandoni and Duszynski, 1988) of sporulated oocysts in the U.S. National Parasite Collection (USNPC) no. 85498 .

Etymology: The nomen triviale is derived from the specific epitaph of the definitive host.

\section{Remarks}

Sporulated oocysts of $E$. albemarlensis resemble in shape those of $E$. tropidura from T. delanonis, Eimeria phelsumae Daszak and Ball 1991 from the "giant day gecko" Phelsuma madagascariensis grandis from Madagascar, and Eimeria anolidis Daszak and Ball 1991 from the common anole Anolis carolinensis. They differ from E. tropidura by being smaller $(27.1 \times 15.6$ vs. $32.5 \times 23.8)$, by being more elongate (SI 1.7 vs. 1.4), having ellipsoidal versus spheroidal sporocysts, and by having a distinct polar body, which $E$. tropidura lacks. They differ from $E$. phelsumae by being slightly smaller $(27.1 \times 15.6$ vs. $31.8 \times 15)$, by being less elongate (SI 1.7 vs. 2.1), by having more elongate sporocysts (SI 1.8 vs. 1.4), and by having a polar body. They differ from $E$. anolidis by being slightly smaller $(27.1 \times 15.6$ vs. $31 \times 15.8)$, by being less elongate (SI 1.7 vs. 2.0), by having more elongate sporocysts (SI $1.8 \mathrm{vs.}$ 1.4), and by lacking a compact and globular sporocyst residuum.

Finally, the sporocysts of this species are unique in that they have the tendency to collapse, even when the oocyst wall remains intact (Figs. 4-6). The configuration of the collapsed sporocyst walls (Figs. 5, 6) closely resemble the 4 platelike structures previously described (light microscopy, transmission electron microscopy [TEM], scanning electron microscopy [SEM]) from sporocysts without a Stieda body in Sarcocystis, Isospora, and Toxoplasma sporocysts (see Duszynski and File, 1974 : fig. 6; Duszynski and Speer, 1976 : figs. 18, 19; Box et al., 1980 : figs 9,10$)$. Unfortunately, we were unable to examine these oocysts in 

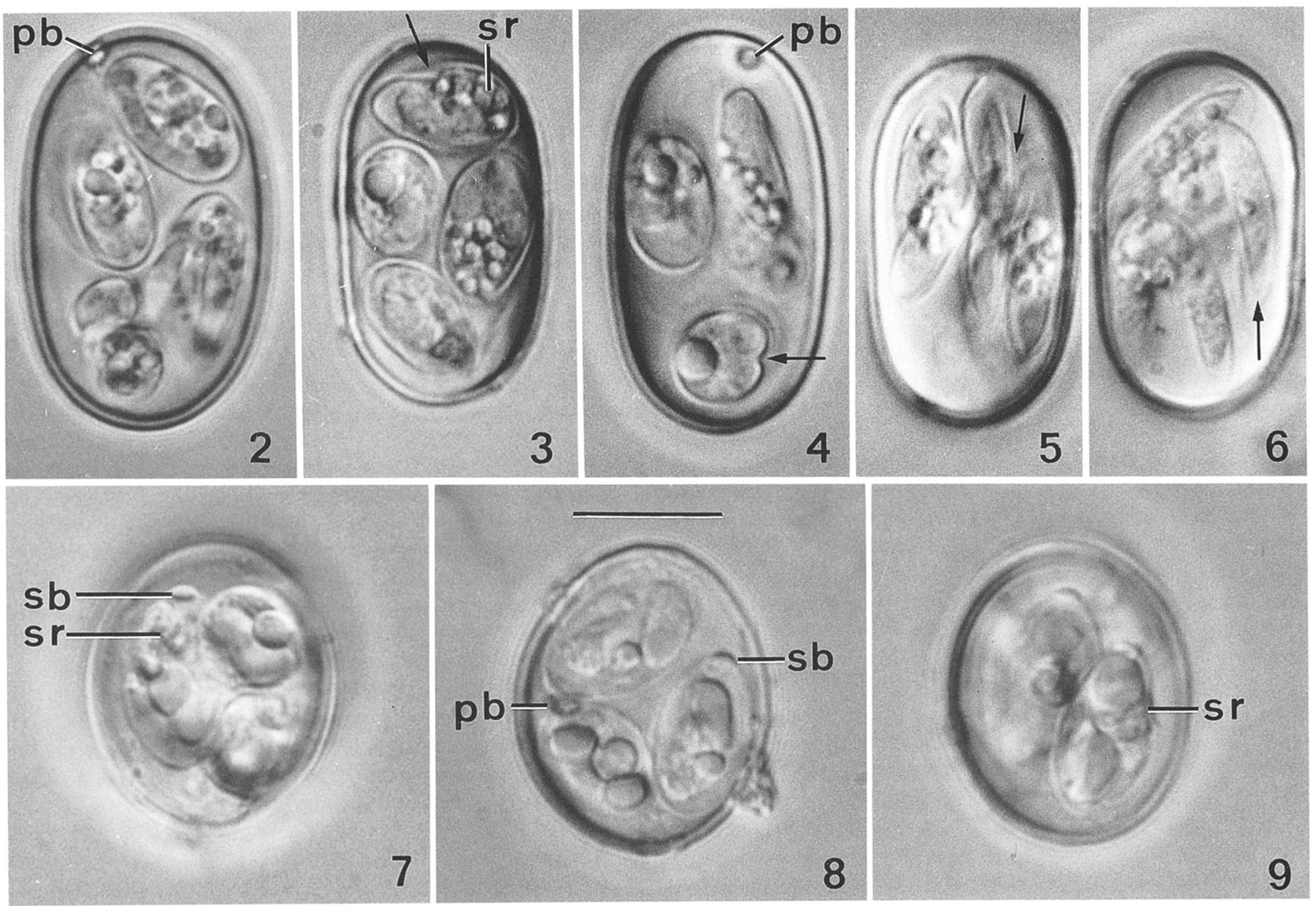

FIGURES 2-9. Photomicrographs of sporulated oocysts of coccidia collected from the feces of Tropidurus albemarlensis (Figs. 2-6) and Geochelone nigra (Figs. 7-9). 2-6. Eimeria albemarlensis n. sp. Note sporocyst residuum of large granules (sr) and distinct refractile polar body (pb). Also note the platelike structures produced from the collapsing of the sporocysts while the oocyst wall remains intact (arrows, 3-6). 7-9. Eimeria geochelona $\mathrm{n}$. sp. Note large granular sporocyst residuum and distinct Stieda body (sb). The polar body is just visible in Figure 8 . Scale bar in Figure $8=10 \mu \mathrm{m}$ for all figures.

more detail using SEM or TEM. To our knowledge, this is the first time that a member of the genus Eimeria has been identified to have sporocysts with wall plates that previously were thought to be characteristic of 2-host coccidians (see discussion in Box et al. [1980]).

\section{DESCRIPTION}

\section{Eimeria geochelona n. sp.}

(Figs. 7-9, 11)

Sporulated oocysts ellipsoidal to ovoidal, wall $\sim 1.5$, composed of 2 smooth, clear layers; outer wall $\sim 1 / 2$ the size of inner wall; micropyle and oocyst residuum absent, but 1-2 distinct large, irregular-shaped refractile polar bodies present (Fig. 8); sporulated oocysts $(n=50) 21.6$ $\times 18.1(18-25 \times 16-20)$ with length: width ratio (=SI) $1.2(1.1-1.4)$; sporocysts $(\mathrm{n}=50)$ ellipsoidal, $10.7 \times 7.0(8-12 \times 5-8)$ with SI 1.5 $(1.3 \times 1.9)$; Stieda body present, but sub- and parastieda bodies absent (Fig. 7-9); sporocyst residuum of medium to large granules randomly distributed among sporocysts (Figs. 7, 9); sporozoites lie side by side along length of sporocyst.

\section{Taxonomic summary}

Type host: Geochelone nigra (Quoy and Gaimard, 1824) (Testudines: Testudinidae).
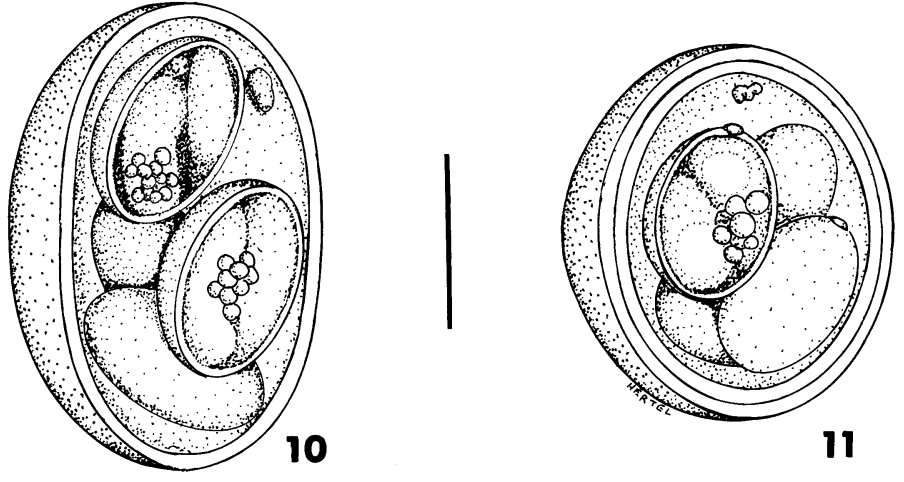

FIGURES 10,11. Line drawings of sporulated oocysts collected from the feces of Tropidurus albemarlensis and Geochelone nigra, respectively. Bar $=10 \mu \mathrm{m}$. 10. Eimeria albemarlensis n. sp. 11. Eimeria geochelona $\mathrm{n}$. sp. 
Type locality: Ecuador, Galápagos Archipelago, Isla Santa Cruz, $0^{\circ} 37^{\prime} 0^{\prime \prime} \mathrm{S}, 90^{\circ} 21^{\prime} 0^{\prime \prime} \mathrm{W}$.

Prevalence: Found in 1 of 26 (4\%) G. nigra from the Charles Darwin Research Station on Isla Santa Cruz.

Site of infection: Unknown, oocysts collected from feces.

Material deposited: Phototype of sporulated oocysts in the U.S. National Parasite Collection (USNPC) no. 85499.

Etymology: The nomen triviale is derived from the specific generic name of the definitive host.

\section{Remarks}

McAllister and Upton (1989) recently summarized the coccidian species described from all turtles. Sporulated oocysts of Eimeria nigra resemble in shape and size those of Eimeria paynei Ernst, Fincher, and Stewart 1971 from the gopher tortoise Gopherus polyphemus from Georgia, U.S.A. and of Eimeria carinii Lainson, Costa and Shaw 1990 from the "jaboti" tortoise Gopherus denticulata from Brazil. They differ from $E$. paynei in having somewhat smaller sporocysts $(10.7 \times 7.0$ vs. 13.2 $\times 8.1)$ and by having randomly distributed, medium to large granules for their sporocyst residuum rather than a mass of small granules enclosed by a thin membrane. They differ from $E$. carinii by being slightly larger $(21.6 \times 18.1$ vs. $19.2 \times 18.6)$, by not having a distinct oocyst residuum, by the presence of a polar body, and by having slightly larger sporocysts $(10.7 \times 7.0$ vs. $8.8 \times 7.3)$ that contain Stieda bodies, which those of $E$. carinii lack.

Ordinarily, we would not describe a new species when it is found only in 1 host because there is a likelihood the coccidian may be a pseudoparasite. We have done so here for the following reasons: (1) there were large numbers of oocysts being discharged by the tortoise and all of the oocysts studied had good structural integrity, which suggests a true infection; (2) the tortoises sampled are kept in pens where contact with most other animals (that may be passing oocysts to result in spurious infections) is limited; (3) only vegetation contaminated by bird or possibly rodent feces might be a source for extraneous oocysts; however, passerine birds have mostly isosporan infections and rodents are not endemic to Isla Santa Cruz; (4) this coccidian does not resemble the eimerian oocysts from introduced rodent pest species, e.g., Rattus spp.; and (5) these tortoises are strict vegetarians (H. L. Snell and P. A. Stone, pers. obs.) and are not inclined to practice copraphagy.

\section{DISCUSSION}

Most studies reporting coccidia that infect reptiles are taxonomic reports. Very little information is available about the evolutionary pressures on, or the physiological ecology of, reptilian hosts as it relates to their coccidial infections. As we continue to study the coccidia that infect lava lizards in the Galápagos, we hope to contribute a parasite component to help answer some preliminary questions relating to these topics. Additionally, lava lizards are ideal study organisms because the Galápagos islands are part of a protected national park system, such that human involvement and their impact on the biology of the lizards, as well as on the parasites that infect them, is minimal.

An important observation we have noted is the variation in the prevalences of the different species of coccidia. Eimeria tropidura is the most common coccidian in lava lizards. Depending on the species of lava lizard, many populations support a second, less prevalent coccidian species, in addition to $E$. tropidura. This pattern could be due to competitive superiority of E. tropidura, or it could be due to other factors such as chance. Data from lizards with infections by more than one species may help resolve this issue. If $E$. tropidura is competitively superior to other coccidian species, we would expect multiple infections to be less common than expected by chance, with the less prevalent species specializing in infecting lava lizards that lacked $E$. tropidura. In fact, the opposite pattern is seen; multiple infec- tions were more common than expected by chance, at least in $T$. delanonis. Thus, the multiple infection pattern does not support an hypothesis of competitive superiority in E. tropidura. Instead, it appears that some lava lizards are more susceptible than others to all coccidian species present in their environment, perhaps because of differences in parasite resistance or habitat selection among lava lizards.

We also had the opportunity to sample some of the giant land tortoises, G. nigra, that are currently under protective care at the Charles Darwin Research Station. Of the samples from the land tortoises, only 1 eimerian species was found, but with great numbers of oocysts being discharged from that tortoise. Thus, because these tortoises are strict vegetarians that may provide some natural resistance to infection (as described below) and for other reasons noted earlier (see Remarks), we describe what we presume to be a new species.

Initially, we assumed that information on the coccidians from the land iguana $C$. subcristatus, and the marine iguana $A$. cristatus, could provide us with interesting comparisons with Tropidurus, especially because 1 or both of these lizards inhabit many of the same islands as the Tropidurus spp. However, neither genus of iguana harbored coccidia. A simple explanation may be related to the diets of the different lizards. Both $C$. subcristatus and $A$. cristatus are herbivores, but under stressful conditions they become opportunists; $C$. subcristatus feeds primarily on fallen or low-growing vegetation, but occasionally will eat insect parts, whereas $A$. cristatus feeds on the algae growing at water level along the base of the island rocks, although they have been seen to eat fish parts and sea lion refuse $(H$. Snell, pers. obs.). Tropidurus spp., on the other hand, routinely feed on both insects and plant material (Stebbins et al., 1967; Schluter, 1984). One conclusion that could be drawn is that insects, by acting as mechanical vectors, may be helping to transmit oocysts to the Tropidurus spp.

Because $C$. subcristatus and $A$. cristatus tend to be herbivorous, it may be that herbivory provides protection against coccidial infections in these animals. For example, certain plants may contain antiparasitic compounds detrimental in some way to the parasite (Crompton, 1987; Lozano, 1991). Other studies conducted with wild chimpanzees in Tanzania have indicated that consumption of some plant materials by the chimps was used for medicinal purposes (Huffman and Seifu, 1989). Whereas we do not mean to imply that the Galápagos lizards are "intentionally" eating certain plants for their medicinal value, the plant material they normally eat fortuitously may provide some medicinal benéfit against certain parasites. Conversely, Sharma et al. (1973) found that in chickens, diets high in protein have been shown to increase susceptibility to infection with coccidia. Because the typical diet of Tropidurus spp. consists of insects that have a high protein content, perhaps they, in turn, make themselves more susceptible to infection by certain parasites like coccidians.

One of the interesting observations in this study is the apparent disappearance of Eimeria galapagoensis Aquino-Shuster, Duszynski, and Snell, 1990 from T. delanonis on Isla Gardner. None of our lava lizard samples from the same island ( $n$ $=142)$, or from 4 other islands that support $T$. delanonis $(\mathrm{n}=$ 329), was infected with this coccidian. Although the prevalence of E. galapagoensis as reported by Aquino-Shuster et al. (1990) was low (4\%), we were surprised not to find it in any of the fecal 
samples. We have no evidence to speculate on the reason(s) for the disappearence of E. galapagoensis from the Archipelago, but given our large sample size, this eimerian may now be locally extinct, or it may be that $E$. galapagoensis was actually a pseudoparasite the lizards acquired while feeding.

\section{ACKNOWLEDGMENTS}

We thank L. A. Hertel for the oocyst line drawings and the UNM Latin American Institute Field Research Program for a Travel Grant (to D.W.D.). We would also like to express our thanks and appreciation to the Charles Darwin Research Station and the Galápagos National Park Service for permission to work in the Archipelago. This research was supported in part by NSF Grant DEB-9521687 to DWD. L. Couch would like to thank the College of A\&S at Albuquerque T-VI for continuing to encourage and support its teaching faculty in research-related activities.

\section{LITERATURE CITED}

Aquino-Shuster, A. L., D. W. Duszynski, AND H. L. Snell. 1990. Three new coccidia (Apicomplexa) from the Hood Island Lizard, Tropidurus delanonis, from the Galápagos Archipelago. Journal of Parasitology 76: 313-318.

BANDONI, S. M., AND D. W. DuszYNSKI. 1988. A plea for improved presentation of type material for coccidia. Journal of Parasitology 74: 519-523.

Box, E. D., A. A. Marchiondo, D. W. Duszynski, and C. P. Davis. 1980. Ultrastructure of Sarcocystis sporocysts from passerine birds and opossums: Comments on classification of the genus Isospora. Journal of Parasitology 66: 66-74.

Cayot, L. J., H. L. SNell, W. Llerena, and H. M. Snell. 1994. Conservation biology of Galápagos reptiles: Twenty-five years of successful management. In Captive management and conservation of amphibians and reptiles, J. B. Murphy, K. Adler, and J. T. Collins (eds.). Society for the Study of Amphibians and Reptiles, Ithaca, New York, p. 297-305.

Crompton, D. W. T. 1987. Host diet as a determinant of parasite growth, reproduction and survival. Mammal Review 17: 117-126.

DuszYNSKI, D. W., G. EASThaM, AND T. L. YATES. 1982. Eimeria from jumping mice (Zapus spp.): A new species and genetic and geographic features of $Z$. hudsonicus luteus. Journal of Parasitology 68: $1146-1148$.

, AND S. K. FILE. 1974. Structure of the oocyst and excystation of sporozoites of Isospora endocallimici $\mathrm{n}$. sp., from the marmoset Callimico goeldii. Transactions of the American Microscopical Society 93: 403-408.

- AND C. A. SPEer. 1976. Excystation of Isospora arctopitheci Rodham, 1933 with notes on a similar process in Isospora bigemina (Stiles, 1891) Lühe, 1906. Zoologie Parasitenkunde 48: 191-197.

Huffman, M. A., AND M. SeIFu. 1989. Observations on the illness and consumption of a possibly medicinal plant Vernonia amygdalina (Del.), by a wild chimpanzee in the Mahale Mountains National Park, Tanzania. Primates 30: 51-63.

IVERSON, J. B. 1992. A revised checklist with distribution maps of the turtles of the world. Privately printed. Richmond, Indiana, p. 250 251.

Lozano, G. A. 1991. Optional foraging theory: A possible role for parasites. Oikos 60: 391-395.

Marquez, C., H. L. Snell, H. M. Snell, S. Rea, M. Wilson, and F. CEPEDA. 1986. The ten year struggle to save the endangered land iquanas. Noticias de Galapagos 44: 9-11.

MCAllister, C. T., AND S. J. UPTON. 1989. The coccidia (Apicomplexa: Eimeriidae) of testudines, with descriptions of three new species. Canadian Journal of Zoology 67: 2459-2467.

SCHLUTER, D. 1984. Body size, prey size and herbivory in the Galápagos lava lizard, Tropidurus. Oikos 43: 291-300.

Sharma, V. D., M. A. Fernando, and J. D. Summers. 1973. The effect of dietary crude protein level on intestinal and cecal coccidiosis in chicken. Canadian Journal of Comparative Medicine 37: 195-199.

SNell, H. L., R. D. Jennings, H. M. SNell, and S. Harcourt. 1988. Intrapopulation variation in predator-avoidance performance of Galápagos lava lizards: The interaction of sexual and natural selection. Evolutionary Ecology 2: 353-369.

- , H. M. SNELl, AND C. R. TRACY. 1984. Variation among populations of Galápagos land iguanas (Conolophus): Contrasts of phylogeny and ecology. Biological Journal of the Linnean Society 21: 185-207.

Stebrins, R. C., J. M. Lowenstein, AND N. W. Cohen. 1967. A field study of the lava lizard (Tropidurus albemarlensis) in the Galapagos Islands. Ecology 48: 839-851.

Stone, P. A. 1995. Sexual selection in lava lizards (Tropidurus). Ph.D. Dissertation. University of New Mexico, Albuquerque, New Mexico, $115 \mathrm{p}$. 